\title{
URGENSI PENGEMBANGAN BUKU DONGENG MOVABLE BERBASIS ETNOSAINS SEBAGAI BAHAN AJAR PENUNJANG PEMBELAJARAN IPA SISWA KELAS IV SEKOLAH DASAR
}

\author{
Izzah Muyassaroh ${ }^{1}$, Titin Sunaryati ${ }^{2}$ \\ ${ }^{12}$ Universitas Pelita Bangsa \\ ${ }^{1}$ izzahmuyassaroh@pelitabangsa.ac.id
}

\begin{abstract}
Transforming textbooks into something interesting and fun for students is now increasingly interesting to study in line with the increasing number of challenges creating children's interest for reading. In order to have an attractive value for children, textbooks need to be specially prepared with a child's point of view which is of course adjusted to the character and level of children's development, learning needs, and the socio-cultural environment. This research is a descriptive qualitative study that aims to identify the urgency of developing ethnoscience based movable fairytale book to support science learning in grade IV Elementary students. This research is a descriptive qualitative study using observation, interview, and questionnaire techniques in data collection. The data analyzed using descriptive analysis techniques according to Miles \& Huberman. The results of the study showed that textbooks that support learning are still limited, reading activities are the most preferred activity during learning but not in leisure, and ethnoscience-based movable fairytale book very hoped to be developed.
\end{abstract}

Keywords: Learning materials, movable books, ethnoscience, elementary school science learning

\begin{abstract}
Abstrak: Mentransformasikan buku ajar menjadi sesuatu yang menarik dan menyenangkan bagi siswa kini semakin menarik untuk dikaji selaras dengan semakin banyaknya tantangan-tantangan menciptakan kecintaan anak terhadap membaca. Agar memiliki nilai ketertarikan bagi anak, buku ajar perlu disusun secara khusus dengan sudut pandang kaca mata anak yang tentunya disesuaikan dengan karakter dan tingkat perkembangan anak, kebutuhan belajar, serta lingkungan sosial budaya. Penelitian ini merupakan penelitian kualitatif deskriptif yang bertujuan untuk mengidentifikasi urgensi pengembangan buku ajar movable dengan konten dongeng etnosains sebagai bahan ajar penunjang pembelajaran IPA pada siswa kelas IV SD. Penelitian ini merupakan penelitian kualitatif deskriptif dengan menggunakan teknik observasi,
\end{abstract}

AR-RIAYAH : Jurnal Pendidikan Dasar vol. 5, no. 1, 2021

IAIN Curup - Bengkulu l p ISSN 2580-362X; e ISSN 2580-3611

http://journal.iaincurup.ac.id/index.php/JPD

DOI: $10.29240 /$ jpd. v5i1.2683 | p. $13-26$ 
wawancara, dan pengisian kuisioner dalam pengumpulan data. Adapun data yang terkumpul kemudian dianalisis dengan teknik analisis deskriptif menurut Miles \& Huberman. Adapun hasil penelitian menunjukkan bahwa buku ajar penunjang pembelajaran masih terbatas, kegiatan membaca merupakan kegiatan yang paling disukai saat pembelajaran namun tidak saat diluar pembelajaran, dan buku ajar berbentuk movable dengan konten yang dikemas dalam bentuk cerita atau dongeng berbasis etnosains sangat diharapkan untuk dikembangkan.

Kata Kunci: Bahan ajar, buku movable, etnosains, pembelajaran IPA $\mathrm{SD}$

\section{PENDAHULUAN}

Membaca merupakan kebutuhan yang fundamental bagi anak. Layaknya orang dewasa, anak juga membutuhkan informasi akan dunia di sekelilingnya yang dapat dijangkau oleh pikirannya sebagai pengembangan identitas diri dan kepribadian. ${ }^{1}$ Salah satu upaya pemenuhan kebutuhan informasi anak dapat dilakukan melalui literatur anak. Dalam dunia pembelajaran, kebutuhan informasi anak salah satunya dipenuhi melalui bahan ajar (learning material). Bahan ajar sebagai segala bentuk bahan yang berisi seperangkat materi yang disusun secara sistematis sehingga tercipta lingkungan atau suasana yang memungkinkan siswa belajar dengan baik. ${ }^{2}$ Bahan ajar disusun secara sistematis dengan menampilkan sosok utuh dari kompetensi yang akan dikuasai dalam pembelajaran. ${ }^{3}$ Seiring berkembangnya zaman, orientasi penyediaan bahan ajar semakin berkembang. Bahan ajar diharapkan tidak hanya memfasilitasi peserta didik untuk mereproduksi pengetahuan, akan tetapi juga memfasilitasi peserta didik untuk berpikir kritis, analitis, reflektif, serta menumbuhkembangkan karakter-karakter.

Peraturan Menteri Pendidikan dan Kebudayaan Indonesia Nomor 23 Tahun 2015 tentang penumbuhan budi pekerti mengisyarakan pentingnya membaca untuk menumbuhkan karakter dan merangsang imaginasi anak. ${ }^{4} \mathrm{Hal}$ ini didukung berdasarkan fakta yang dilansir oleh Kompas edisi 15 Desember 2016 bahwa siswa sekolah dasar di Indonesia unggul dalam hafalan namun daya

\footnotetext{
${ }^{1}$ Nurgiyantoro, B. (2013). Sastra Anak. Yogyakarta: Gadjah Mada University Press.

2 Depdiknas. (2008). Panduan Pengembangan Bahan Ajar. Jakarta: Departemen Pendidikan Nasional.

3 Prastowo, A. (2014). Pengembangan Bahan Ajar Tematik:Tinjauan Teoritis dan Praktik. Jakarta: Kencana Prenada Media Group.

${ }^{4}$ Peraturan Menteri Pendidikan dan Kebudayaan Indonesia Nomor 23 Tahun 2015 tentang penumbuhan budi pekerti
} 
imaginasi dan kemampuan literasi siswa SD masih lemah. ${ }^{5}$ Berdasarkan hasil Indonesia National Assesment Program yang dilakukan oleh Pusat Penelitian Pendidikan Kementerian Pendidikan dan Kebudayaan mengungkapkan bahwa rata-rata nasional kemampuan membaca pelajar Indonesia yaitu 46,83\% berada pada kategori kurang, 47,11\% berada pada kategori cukup, dan hanya 6,06\% berada dalam kategori baik. ${ }^{6}$ Fakta ini juga didukung hasil PISA terbaru tahun 2018 dimana skor membaca siswa Indonesia berada di peringkat 72 dari 77 negara yang berpartisipasi. ${ }^{7}$ Selain itu, studi lain yang dilakukan oleh Progress in International Reading Literacy Study (PIRLS) dan Early Grade Reading Assessment (EGRA) juga menunjukkan hasil yang tidak jauh berbeda dengan PISA. Data lain mengenai kemampuan literasi juga dirilis oleh Central Connecticut State University Amerika Serikat mengenai World's Most Literate Nations pada tahun 2017 juga menunjukkan bahwa Indonesia berada pada peringkat 60 dari 61 negara yang berpartisipasi dalam survei. ${ }^{8}$

Di era globalisasi ini, buku sastra dalam kehidupan sehari-hari kurang diminati oleh anak, namun dalam dunia pendidikan kedudukan buku sebagai bahan ajar pada berbagai jenjang pendidikan masih menjadi sarana utama anak memperoleh informasi dalam pembelajaran. ${ }^{9,10}$ Berbagai penelitian dan upaya pengembangan bahan ajar khususnya dalam bentuk buku bertebaran untuk mengkreasikan buku menjadi wujud yang menarik bagi anak dan menunjukkan kepada mereka bahwa pengalaman dengan buku menyenangkan. Pengembangan buku anak tidak hanya dilakukan dari segi bentuk tetapi juga dari segi konten. Dari segi bentuk, buku dikembangkan dengan berbagai bentuk yang unik dan menarik seperti $p o p$ up ${ }^{11}$, Augmented Reality 3D Pop $U p^{12}$, flip, volvela ${ }^{13}$, buku

${ }^{5}$ Krisiandi. (15 Desember 2016).Daya Imajinasi Siswa Lemah. Harian Kompas, hlm.11.

6 Kemdikbud. (2017). Hasil Indonesian National Assesment Programme (INAP). Retrieved from https://puspendik.kemdikbud.go.id/inap-sd/

7 OECD. (2018). Indonesia-Country Note - Results from PISA 2015 (p. 8). Retrieved from OECD website: www.oecd.org/pisa

8 Mendikbud. (2019). Mengejar ke Barat, Utara, dan Timur. Retrieved from https://indonesia.go.id/kategori/indonesia-dalam-angka/1013/mengejar-ke-barat-utara-dantimur

${ }^{9}$ Klein, G. (2002).Reading into racism: bias in children's literature and learning materials. New York: Taylor \& Francis e-Library. https://doi.org/10.4324/9780203076705

${ }^{10}$ Faradina, N. (2017). Pengaruh Program Gerakan Literasi Sekolah terhadap Minat Baca Siswa di SD Islam Terpadu Muhammadiyah An-Najah Jatinom Klaten. Jurnal Hanata Widya 6(8), 60-69.

${ }^{11}$ Marcus, L.S. (2013). Pop-Ups on Parade: Art, Novelty, and the Book Reimagined. New York: IPCNY

12 Vate-U-lan, P. (2011) Augmented Reality 3D Pop-up Children Book: Instructional Design for Hybrid Learning. Proceedings of IEEE International Conference, Melbourne. 95-100. DOI:10.1109/ICELIE.2011.6130033

${ }^{13}$ Dyk, S.V \& Hewitt, C. (2011). Paper Engineering: Fold, Pull, Pop, \& Turn. Washington DC: Smithsonian Institution. 
movable ${ }^{14}$, dan buku mainan atau toy book. Dari segi konten, buku dikreasikan melalui jenisnya (fiksi dan non-fiksi), penggunaan bahasa, serta variasi dari unsur-unsur instrinsik dan ekstrinsiknya.

Bacaan atau literatur anak berbeda dengan orang dewasa. Literatur anak dibuat dari kacamata anak meskipun pembuatnya adalah orang dewasa. Bagaimanapun kandungan isi literatur anak dibatasi oleh pengetahuan dan pengalaman yang dapat dijangkau dan dipahami anak, serta sesuai dengan tahap perkembangannya. Hal tersebut merupakan isu fundamental bagi anak untuk memahami dan memperoleh informasi dari bacaan. Seringkali batas antara literatur anak dengan literatur orang dewasa kabur ${ }^{15}$ dan bahan ajar yang benarbenar sesuai dengan kebutuhan dan karakteristik siswa tidak selalu tersedia. ${ }^{16}$ Terkadang ditemukan baik literatur maupun bahan ajar pembelajaran anak yang kurang sesuai dengan tingkat perkembangan dan karakteristik usia anak karena kurangnya kajian mendalam dan penelitian empiris. Bahan ajar dikembangkan sebagai alat bantu dalam pemecahan masalah spesifik yang berkaitan dengan pembelajaran. ${ }^{17}$ Oleh karena itu, literatur dan bahan ajar untuk anak perlu disusun secara khusus yang disesuaikan dengan tingkat perkembangan dan lingkungan sosial budaya anak.

Berdasarkan permasalahan-permasalahan yang telah dipaparkan tersebut, peneliti berinisiatif untuk melakukan penelitian guna mengidentifikasi urgensi pengembangan buku ajar movable dengan konten dongeng etnosains sebagai bahan ajar penunjang pembelajaran IPA pada siswa kelas IV SD. Buku dongeng movable berbasis etnosains merupakan salah satu bentuk upaya mengkreasikan buku dari segi bentuk maupun konten. Dari segi bentuk, buku ini mentransformasikan bentuk buku yang statis menjadi dinamis tiga dimensi berbentuk movable. Movable berasal dari kata move dan able yang dalam bahasa Inggris berarti dapat digerakan. Buku movable dapat digerakkan secara flip, tarik tab, poros, slot, roda, dan pop up..$^{18,19,20}$ Penggunaan movable book menjadikan tampilan buku menjadi menarik, komunikatif dan interaktif dengan

${ }^{14}$ Sarlatto, M. (2016). Paper Engineers and Mechanical Devices of Movable Books of The 19th and 20th Centuries. JLIS.it. 7(1), 89-112. DOI: 10.4403/jlis.it-11610.

${ }^{15}$ Huck, C.S., Hepler, S., \& Hickman, J. (1987). Children's Literature in The Elementary School. New York: Holt, Rinehart and Wiston.

${ }^{16}$ Harsono, Y. M. (2007). Developing Learning Material for Specific Purpose. TEFLIN Journal. 18(2), 169-179.

17 Bundsgaard \& Hansen. (2011). Evaluation of Learning Materials: A Holistic Framework. Journal of Learning Design. 4(4), 31-44.

18 Dyk, S.V \& Hewitt, C. (2011). Paper Engineering: Fold, Pull, Pop, \& Turn. Washington DC: Smithsonian Institution.

19 Abrahamson,R.F \& Stewart, R.(1982). Movable Books-A New Golden Age. NCTE, 59(4), 342-347.

${ }^{20}$ Marcus, L.S. (2013). Pop-Ups on Parade: Art, Novelty, and the Book Reimagined. New York: IPCNY 
menghadirkan objek-objek ilustrasi bergerak yang membuat informasi/cerita menjadi lebih hidup. ${ }^{21}$ Dari segi konten, buku ini mengkombinasikan dongeng dan etnosains. Ethnosains merupakan pendekatan atau studi tentang budaya (bahasa, jargon, kode, perilaku, mitos, simbol, pemikiran) dalam suatu masyarakat tertentu yang menginterpretasikan sains untuk menciptakan kurikulum yang relevan dengan peserta didik. ${ }^{22}$ Banyak yang beranggapan bahwa dongeng dan sains merupakan dua hal yang tidak dapat dipadukan, dimana dongeng bersifat imaginatif, fantasi, dan dikenal dengan daya khayal. Sementara sains merupakan pengetahuan sistematis yang bersifat logis, kebenaran didapatkan melalui metode ilmiah. Namun tidak demikian, dongeng memiliki peran penting dalam membangun imaginasi ${ }^{23}$, dimana imaginasi memainkan peranan penting dalam pembentukan pengetahuan dan penemuan ilmiah. ${ }^{24}$ Terlebih untuk sekolah dasar dimana daya fantasi dan imaginasi masih mendominasi dalam kemampuan berpikir mereka. Daya imaginasi dan fantasi sangat penting pada masa anak-anak, namun jarang dikaitkan dalam pembelajaran. Pembelajaran cenderung serius dan kaku mengingat banyaknya tuntutan penguasaan atau kompetensi yang harus diajarkan.

Buku dongeng Movable berbasis Ethnosains disusun untuk membantu pembelajaran sains melalui karya sastra sebagai batu loncatan siswa mempelajari sains. Siswa memperoleh pengetahuan yang mereka dapatkan melalui dongeng yang mereka baca sebagai dasar untuk mempelajari materi sains. Buku ini disusun dengan mengolah sains melalui sastra anak, memberikan perhatian khusus pada setiap konsep yang disertai kegiatan pembuktian sains, studi sosial, dan seni bahasa yang disesuaikan dengan tahap perkembangan anak. Anak-anak merasa lebih mudah mengikuti gagasan yang menjadi bagian dari alur cerita daripada memahami fakta seperti yang disajikan dalam buku teks.Sebuah cerita menempatkan fakta dan konsep ke dalam bentuk yang mendorong anak untuk membangun hipotesis, memprediksi kejadian, mengumpulkan data, dan menguji keabsahan kejadian. Hal ini sebagai upaya untuk mengurangi pembelajaran sains sebagai fakta yang dihafal. Anak memahami kerangka konseptual serta faktafakta yang terhubung satu sama lain dengan dunia tempat tinggal mereka.

${ }^{21}$ Sarlatto, M. (2016). Paper Engineers and Mechanical Devices of Movable Books of The $19^{\text {th }}$ and $20^{\text {th }}$ Centuries. JLIS.it. 7(1), 89-112. DOI: $10.4403 /$ jlis.it-11610.

22 Fasasi, R.A. (2017). Effects of Ethnoscience Instruction, School Location, and Parental Educational Status on Learners' Attitude Towards Science, International Journal of Science Education, DOI: 10.1080/09500693.2017.1296599

23 Ahyani, L. N., \& Kudus, U. M. (2010). Metode Dongeng Dalam Meningkatkan Perkembangan. Jurnal Psikologi, I(1), 24-32.

${ }_{24}$ Downie, R. (2001). Science and the Imagination in the Age of Reason. Medical Humanities, 27(2), 58-63. https://doi.org/10.1136/mh.27.2.58 


\section{METODE PENELITIAN}

Penelitian ini merupakan penelitian deskriptif kualitatif dengan metode survei. Teknik pengumpulan data yang digunakan yaitu observasi, wawancara, dan angket. Subjek penelitian yaitu 155 siswa dan 6 guru kelas IV SD di 5 sekolah se-kota Yogyakarta. Data-data dikumpulkan dengan menggunakan instrumen pedoman observasi, pedoman wawancara, dan angket terhadap siswa untuk mengetahui minat siswa terhadap buku dan gambaran mengenai buku yang diharapkan siswa. Penelitian ini dilakukan selama 3 bulan dari bulan September - November. Data hasil observasi, wawancara, dan angket dianalisis dengan menggunakan teknik analisis deskriptif menurut Miles \& Huberman dengan langkah-langkah mengumpulkan data melalui observasi, wawancara, dan dokumentasi, kemudian mereduksi data yang diperoleh dari lapangan, membuat sajian data dan menarik kesimpulan.

\section{HASIL DAN PEMBAHASAN}

Faktor utama penentu keberhasilan kurikulum 2013 diantaranya yaitu kesesuaian tenaga pendidik dan kependidikan dengan kurikulum dan buku teks serta faktor pendukung yaitu ketersediaan buku sebagai bahan ajar dan sumber belajar yang mengintegrasikan standar pembentuk kurikulum. ${ }^{25}$ Dalam proses pembelajaran, terdapat beberapa masalah penting yang dihadapi guru terkait ketersediaan bahan ajar yang tepat dalam membantu siswa mencapai kompetensi.Salah satunya, guru memberikan bahan ajar dengan materi yang terlalu luas atau mendalam dengan urutan penyajian yang tidak sistematis dan tidak difokuskan pada pencapaian kompetensi tertentu. ${ }^{26}$ Masalah lainnya yaitu siswa mengalami kesulitan dalam mengikuti proses pembelajaran sains tematik dengan bahan ajar yang ada serta mengalami kesulitan dalam mencari sumber lain dalam memahami materi yang dipelajari. ${ }^{27} \mathrm{Hal}$ ini selaras dengan hasil wawancara terhadap beberapa guru SD di Yogyakarta yang mengemukakan bahwa buku ajar penunjang pembelajaran tematik masih terbatas dan pengembangan buku ajar penunjang pembelajaran kurikulum 2013 sangat dibutuhkan. Adapun secara rinci mengenai hasil wawancara terhadap guru mengenai buku ajar disajikan sebagai berikut:

${ }^{25}$ Kementrian Pendidikan dan Kebudayaan Republik Indonesia. (2016). Desain Induk Gerakan Literasi Sekolah. Jakarta: Depdikbud.

${ }^{26}$ Ermanda, S. \& Ariandani, N. (2020). Pengembangan Bahan Ajar IPA Berbasis Lingkungan Di Sekolah Dasar Negeri 3 Jenggik Tahun Pelajaran 2017/2018. BADA'A: Jurnal Ilmiah Pendidikan Dasar, 2(1): 99-107. DOI: https://doi.org/10.37216/badaa.v2i1.289

${ }^{27}$ Syofyan, H., Zulela, \& Sumantri, M.S. (2019). Pengembangan Awal Bahan Ajar IPA Di Sekolah Dasar. JPD: Jurnal Pendidikan Dasar. 10(1). 52-67 DOI: doi.org/10.21009/JPD.010.06 


\begin{tabular}{|c|c|c|c|}
\hline \multirow[t]{2}{*}{ No } & \multirow[t]{2}{*}{ Pertanyaan } & \multicolumn{2}{|c|}{$\begin{array}{l}\text { Persentase } \\
\text { Jawaban }\end{array}$} \\
\hline & & Ya & Tidak \\
\hline 1. & Apakah buku penting dalam kegiatan pembelajaran? & $100 \%$ & $0 \%$ \\
\hline 2. & $\begin{array}{l}\text { Apakah Anda merasa buku penunjang pembelajaran } \\
\text { masih terbatas? }\end{array}$ & $100 \%$ & $0 \%$ \\
\hline 3. & $\begin{array}{l}\text { Apakah Anda membutuhkan buku penunjang } \\
\text { pembelajaran? }\end{array}$ & $100 \%$ & $0 \%$ \\
\hline 4. & $\begin{array}{l}\text { Adakah buku lain selain buku teks guru dan siswa yang } \\
\text { Anda gunakan untuk menunjang proses pembelajaran } \\
\text { tematik? }\end{array}$ & $33 \%$ & $67 \%$ \\
\hline 5. & $\begin{array}{l}\text { Apakah buku-buku penunjang pembelajaran yang } \\
\text { tersedia sudah mampu memfasilitasi pencapaian } \\
\text { kompetensi siswa? }\end{array}$ & $33 \%$ & $67 \%$ \\
\hline 6. & $\begin{array}{l}\text { Apakah buku ajar yang digunakan telah relevan dengan } \\
\text { kebutuhan dan karakteristik siswa? }\end{array}$ & $33 \%$ & $67 \%$ \\
\hline 7. & $\begin{array}{l}\text { Apakah Anda mengembangkan sendiri buku ajar dalam } \\
\text { pembelajaran? }\end{array}$ & $0 \%$ & $100 \%$ \\
\hline 8. & $\begin{array}{l}\text { Apakah buku ajar pembelajaran perlu dikembangkan } \\
\text { sesuai dengan lingkungan sosial budaya siswa? }\end{array}$ & $100 \%$ & $0 \%$ \\
\hline 9. & $\begin{array}{l}\text { Apakah buku ajar yang ada sudah dikembangkan sesuai } \\
\text { lingkungan sosial budaya siswa? }\end{array}$ & $17 \%$ & $83 \%$ \\
\hline 10. & $\begin{array}{l}\text { Adakah buku ajar pembelajaran yang Anda gunakan } \\
\text { disajikan dalam bentuk dongeng? }\end{array}$ & $0 \%$ & $100 \%$ \\
\hline 11. & $\begin{array}{l}\text { Perlukah bahan ajar yang ada disajikan dalam bentuk } \\
\text { dongeng? }\end{array}$ & $83 \%$ & $17 \%$ \\
\hline 12. & $\begin{array}{l}\text { Pernahkah Anda mengajarkan materi sains dengan } \\
\text { mendongeng? }\end{array}$ & $17 \%$ & $83 \%$ \\
\hline 13. & $\begin{array}{l}\text { Apakah buku ajar yang ada telah mengintegrasikan } \\
\text { budaya lokal daerah? }\end{array}$ & $33 \%$ & $67 \%$ \\
\hline 14. & Apakah Anda mengetahui buku movable?* & $0 \%$ & $100 \%$ \\
\hline 15. & $\begin{array}{l}\text { Perlukah buku movable dikembangkan sebagai buku ajar } \\
\text { siswa? }\end{array}$ & $100 \%$ & $0 \%$ \\
\hline 16. & $\begin{array}{l}\text { Sudah tersediakah buku ajar berbentuk movable di } \\
\text { sekolah? }\end{array}$ & 10 & $100 \%$ \\
\hline
\end{tabular}

Tabel 1.1 hasil wawancara terhadap guru mengenai bahan ajar

Berdasarkan tabel tersebut, diketahui bahwa guru merasa sangat membutuhkan buku ajar penunjang pelaksanaan kurikulum 2013 sebagai pelengkap buku teks yang telah tersedia. Namun disisi lain guru merasa kesulitan dan kurang percaya diri untuk mengembangkan buku ajar secara mandiri. Hal ini 
sangat disayangkan, karena guru merupakan posisi paling potensial sebagai pengembang buku ajar yang sesuai dengan permasalahan dan karakteristik peserta didik. ${ }^{28}$ Menurut guru, buku ajar yang disesuaikan dengan lingkungan sosial budaya di sekitar sangat perlu dikembangkan agar siswa mengetahui identitas bangsanya, lebih aplikatif, serta tidak merasa asing dengan konsep yang dibahas. Pembelajaran sains berbasis literature oriented masih jarang dilakukan oleh guru karena keterbatasan waktu dan sulitnya pengembangan cerita untuk mengantarkan materi sains. Mengenai buku movable, guru masih merasa asing dengan istilah tersebut. Guru merasa antusias dan buku movable dianggap perlu untuk dikembangkan mengingat belum tersedianya buku tersebut di sekolah.

Selain mengadakan wawancara terhadap guru, peneliti juga memberikan angket dan wawancara terhadap siswa mengenai buku bacaan dan buku pembelajaran yang digunakan siswa. Berdasarkan hasil angket dan didukung oleh wawancara terhadap beberapa siswa dihasilkan data sebagai berikut. Adapun persentase kegiatan yang dilakukan siswa di luar sekolah ditampilkan sebagai berikut.

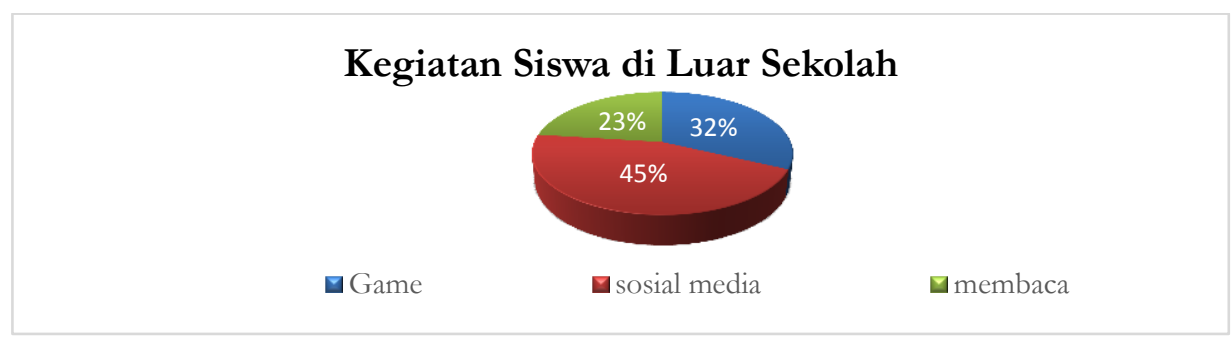

Gambar 1.1 Diagram Kegiatan Siswa di Luar Sekolah

Setelah dilakukan wawancara, siswa cenderung tidak suka membaca buku dengan alasan membuat mengantuk, bosan, serta buku tidak menarik. Sedangkan siswa yang suka membaca buku dengan alasan buku membuat mereka pintar, mengetahui banyak hal, mendapat hadiah, dan cerita menarik. Hal ini didukung dengan poin selanjutnya yaitu mengenai intensitas membaca yang dilakukan siswa di luar jam sekolah disajikan dalam diagram berikut.

${ }^{28}$ Harsono, Y. M. (2007). Developing Learning Material for Specific Purpose. TEFLIN Journal. 18(2), 169-179. 


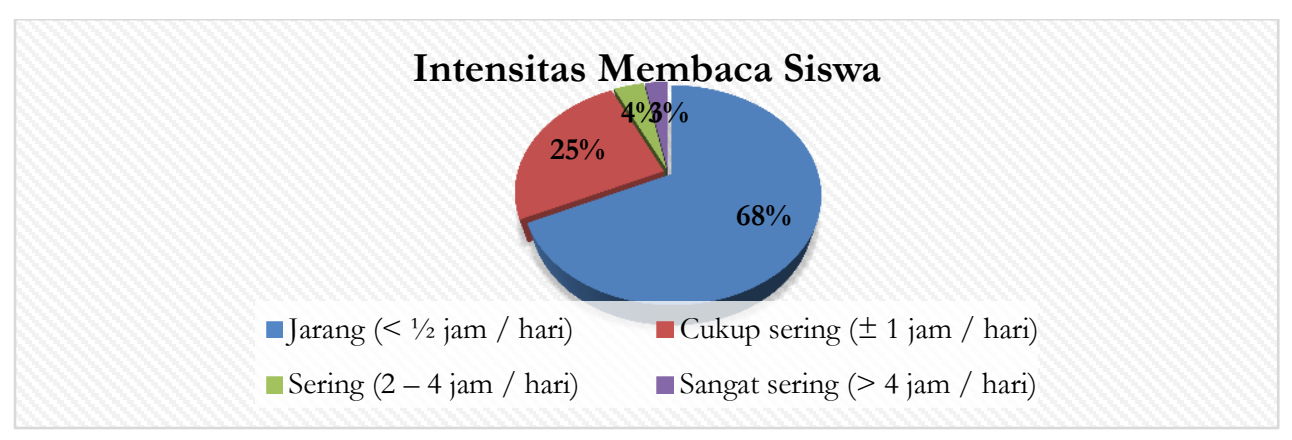

Gambar 1.2. Diagram Intentensitas Membaca Siswa di Luar Pembelajaran

Hasil angket menunjukkan bahwa 68\% siswa membaca buku diluar jam pelajaran rata-rata kurang dari 30 menit sehari. Minat membaca anak khususnya pada jenjang sekolah dasar masih rendah. ${ }^{29,30}$ Buku sebagai bahan ajar hanya dibaca untuk keperluan pembelajaran seperti saat pembelajaran berlangsung dan mengerjakan tugas. Rendahnya minat baca juga didukung data yang dirilis oleh Badan Pusat Statistik (BPS) pada tahun 2012 bahwa 91,68\% masyarakat Indonesia lebih memilih untuk menonton televisi dari pada membaca. ${ }^{31}$

Hal tersebut sangat ironis jika disandingkan dengan hasil angket poin selanjutnya dimana membaca merupakan aktivitas paling disukai siswa dalam kegiatan pembelajaran. Mengenai kegiatan dalam pembelajaran, siswa paling banyak memilih kegiatan membaca yaitu sebesar 93\%. Setelah itu disusul kegiatan mendengarkan $78 \%$, menulis $70 \%$, melakukan percobaan $67 \%$, menghafal $63 \%$, berbicara $50 \%$, diskusi kelompok 53\%, dan menghitung 48\%. Diagram mengenai kegiatan yang disukai siswa saat pembelajaran disajikan sebagai berikut.

Data tersebut menunjukkan bahwa kegiatan membaca menjadi kegiatan yang paling disukai siswa saat pembelajaran, namun tidak saat kegiatan diluar pembelajaran. Buku dalam kehidupan sehari-hari kurang diminati oleh anak, namun dalam dunia pendidikan kedudukan buku sebagai bahan ajar pada berbagai jenjang pendidikan masih menjadi sarana utama anak memperoleh informasi dalam pembelajaran. ${ }^{32,33}$ Respon siswa mengenai kemenarikan buku

${ }^{29}$ Bua, Santoso, \& Hasanah. (2016). Analisis Minat Membaca Permulaan dengan Cerita Bergambar di Kelas I Sekolah Dasar. Jurnal Pendidikan: Teori, Penelitian, dan Pengembangan, 1(9): 1749-1752

${ }^{30}$ Triatma, I.N. (2016). Minat Baca pada Siswa Kelas VI Sekolah Dasar Negeri Delegan. E-Jurnal Prodi Teknologi Pendidikan, 5(6): 166-178

${ }^{31}$ Badan Pusat Statistik. (2019). Statistik Telekomunikasi Indonesia 2018. Retrieved from https://www.bps.go.id/publication/2019/12/02/6799f23db-22e9bdcf52c8e03/_statistiktelekomunikasi-indonesia-2018.html

32 Klein, G. (2002).Reading into racism: bias in children's literature and learning materials. New York: Taylor \& Francis e-Library. https://doi.org/10.4324/9780203076705 
kurikulum 2013 (buku siswa) baik. Hal ini ditunjukkan bahwa 81\% siswa menilai bahwa buku tema siswa menarik. Siswa merasa bahwa buku tersebut menarik karena penuh warna, banyak aktivitas, dan berisi gambar-gambar menarik.

Jenis buku yang dibaca anak beragam. Saat disajikan beberapa pilihan, sebagian besar anak suka membaca buku cerita dan komik. Adapun persentase siswa yang menyukai buku cerita atau dongeng sebesar 53\%, komik 36\%, majalah 5\%, dan umum 6\%. Data mengenai jenis buku bacaan yang disukai siswa disajikan pada diagram berikut.

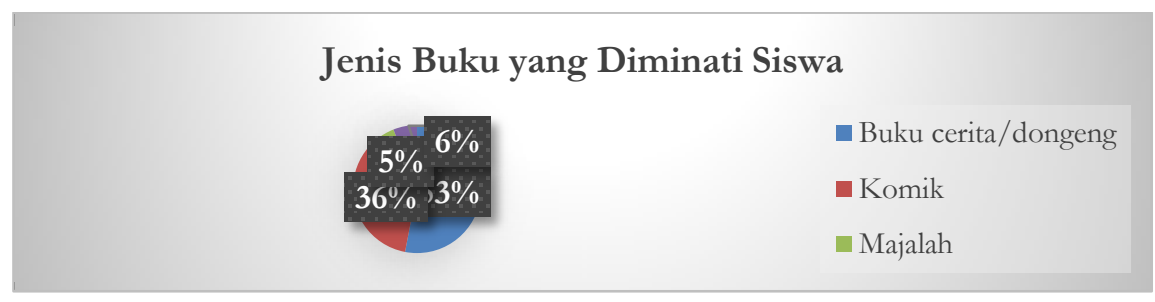

Gambar 1.3. Diagram Mengenai Jenis Buku yang Diminati Siswa

Dongeng atau cerita dapat dimanfaatkan di segala jenjang afektif dan intelektual, sekaligus dapat memperkuat pengalaman pribadi. Adapun jenis cerita yang paling diminati oleh siswa yaitu cerita atau dongeng petualangan. Hal ini didasarkan pada hasil angket siswa yang menunjukkan bahwa $40 \%$ siswa menyukai cerita petualangan, $25 \%$ cerita lucu, $21 \%$ cerita menyeramkan, dan 14\% cerita rakyat. Hal ini senada dengan hasil penelitian Faradina (2017) bahwa siswa usia SD lebih cenderung menyukai buku bergambar non-fiksi berbentuk cerita petualangan

Mengenai isi buku, siswa boleh mengisi lebih dari satu pilihan. Hasil angket menunjukkan bahwa 21\% siswa memilih budaya daerah, $24 \%$ latihan soal, $47 \%$ materi pelajaran, $66 \%$ cerita atau dongeng, dan 58\% gambar. Hal ini menunjukkan bahwa buku berkonten kebudayaan daerah masih menjadi buku yang kurang diminati siswa, sedangkan buku cerita atau dongeng merupakan yang paling diminati siswa. Dengan begitu, menggabungkan dongeng yang mengandung unsur budaya merupakan solusi yang strategis untuk meningkatkan minat siswa mempelajari dan memahami budaya daerahnya.

${ }^{33}$ Faradina, N. (2017). Pengaruh Program Gerakan Literasi Sekolah terhadap Minat Baca Siswa di SD Islam Terpadu Muhammadiyah An-Najah Jatinom Klaten. Jurnal Hanata Widya 6(8), 60-69. 


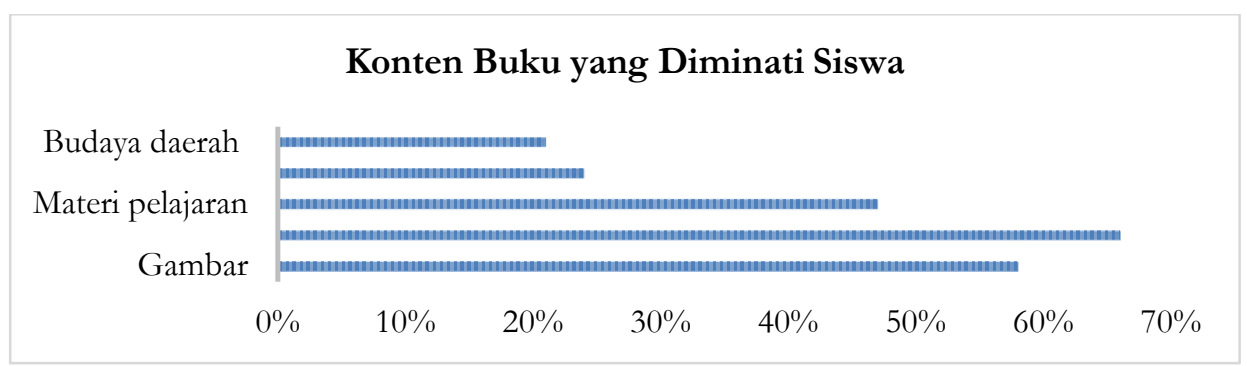

Gambar 1.4. Diagram Mengenai Konten Buku yang Diminati Siswa

Dari segi bentuk, anak lebih menyukai buku movable dibandingkan buku datar. Berdasarkan hasil angket, 68\% siswa menyukai buku berbentuk movable. Berdasarkan hasil wawancara siswa merasa bahwa buku movable lebih menarik karena lebih indah, bisa dimainkan, memberikan efek timbul, dapat bergerak, dan belum tersedia di sekolah mereka. Bentuk tiga dimensi bergerak (movable) dirancang seperti buku mainan yang memberikan efek keindahan dan kejutan dalam setiap halaman, menjadikan buku menjadi lebih interaktif, membuat informasi atau cerita dalam buku menjadi lebih hidup, serta memvisualisasikan konsep-konsep abstrak menjadi lebih konkret. ${ }^{34,35}$

Guru diharapkan mampu mengembangkan bahan ajar dengan menggunakan berbagai macam media dan potensi yang ada. ${ }^{36}$ Dengan bahan ajar, guru dapat mengelola kegiatan pembelajaran secara efektif dan efisien, siswa pun dapat terlibat aktif dan mengikuti kegiatan pembelajaran secara optimal. ${ }^{37}$ Pengembangan buku ajar movable berbasis etnosains dirasa sangat dibutuhkan. Selain menjawab berbagai persoalan terhadap penggunaan bahan ajar dalam pembelajaran, konten buku memiliki potensi yang lengkap untuk mendukung keberhasilan pembelajaran IPA. Pendekatan pembelajaran dengan memanfaatkan budaya sebagai sumber kurikulum merupakan landasan filosofis kurikulum 2013. Pembelajaran anak usia sekolah dasar sebaiknya dikemas secara kontekstual dengan mengeksplor lingkungan sekitar siswa seperti lingkungan rumah, sekolah, tempat bermain, komunitas lokal, dan kebudayaan. ${ }^{38}$ Pembelajaran dengan etnosains juga didasarkan pada Teori Vygotsky yang

${ }^{34}$ Dyk, S.V \& Hewitt, C. (2011). Paper Engineering: Fold, Pull, Pop, \& Turn. Washington DC: Smithsonian Institution.

35 Sarlatto, M. (2016). Paper Engineers and Mechanical Devices of Movable Books of The $19^{\text {th }}$ and $20^{\text {th }}$ Centuries. JLIS.it. 7(1), 89-112. DOI: 10.4403/jlis.it-11610.

36 Wardani, P. T., Alwi, M., \& Hakim, A. R. (2020). Pengembangan Bahan Ajar Ipa

Kelas V Sekolah Dasar Menggunakan Multimedia Interaktif Berbantuan Animasi. Prima Magistra: Jurnal Ilmiah Kependidikan. 1(2): 191-198. DOI: https://doi.org/10.37478/jpm.v1i2

37 Tianisa, W. T. (2017). Analisis Kebutuhan Buku Ajar Matematika Berbasis Model Pembelajaran Guided Discovery. The 5th Urecol Prosiding. Universitas Ahmad Dahlan

38 McLain,M., McLain,M., Tsai,J., Martin,M., Bell,D., \& Wooff, D. (2016). Traditional

Tales and Imaginary Contexts in Primary Design and Technology: A case study. Design and Technology Education Journal. 22(2), 26-40. 
mengungkapkan bahwa belajar akan lebih efektif jika melibatkan lingkungan sosiokultural, di mana lingkungan sosial dan budaya memainkan peranan penting dalam perkembangan kognisi. ${ }^{39}$

\section{KESIMPULAN}

Berdasarkan hasil penelitian dapat disimpulkan bahwa kegiatan membaca diluar pembelajaran masih belum terlalu diminati siswa jika dibandingkan dengan aktivitas bermain game atau berselancar di sosial media. Namun dalam pembelajaran, membaca menjadi aktifitas yang paling diminati siswa. Ketersediaan buku ajar penunjang kurikulum 2013 masih sangat terbatas dan pengembangan bahan ajar yang spesifik sesuai dengan kebutuhan dan karakteristik siswa sangat diharapkan. Buku dongeng movable berbasis etnosains perlu dikembangkan sebagai salah satu bentuk inovasi pengembangan buku ajar yang menarik dalam menunjang pembelajaran IPA siswa kelas IV SD. Bentuk movable pada buku mengubah konsep buku yang statis menjadi lebih dinamis dan interaktif sehingga menambah daya tarik siswa. Terlebih dengan memadukan konten budaya, sains, dan dongeng membuat pembelajaran IPA lebih aplikatif.

\section{DAFTAR PUSTAKA}

Abrahamson,R.F \& Stewart, R.(1982). Movable Books-A New Golden Age. NCTE, 59(4)

Ahyani, L. N., \& Kudus, U. M. (2010). Metode Dongeng Dalam Meningkatkan Perkembangan. Jurnal Psikologi

Badan Pusat Statistik. (2019). Statistik Telekomunikasi Indonesia 2018

Bua, Santoso, \& Hasanah. (2016). Analisis Minat Membaca Permulaan dengan

Cerita Bergambar di Kelas I Sekolah Dasar. Jurnal Pendidikan: Teori, Penelitian, dan Pengembangan

Bundsgaard \& Hansen. (2011). Evaluation of Learning Materials: A Holistic Framework. Journal of Learning Design

Depdiknas. (2008). Panduan Pengembangan Baban Ajar. Jakarta: Departemen Pendidikan Nasional.

Downie, R. (2001). Science and the Imagination in the Age of Reason.

Dyk, S.V \& Hewitt, C. (2011). Paper Engineering: Fold, Pull, Pop, \& Turn. Washington DC: Smithsonian Institution.

\footnotetext{
${ }^{39}$ Schunk, D. (2012). Learning Theories An Educational Perspectives:Teori Pembelajaran Perspektif Pendidikan Edisi Keenam. Penerjemah: Eva Hamdiah \& Rahmat Fajar. Yogyakarta: Pustaka Pelajar.
} 
Ermanda, S. \& Ariandani, N. (2020). Pengembangan Bahan Ajar IPA Berbasis Lingkungan Di Sekolah Dasar Negeri 3 Jenggik Tahun Pelajaran 2017/2018. BADA'A: Jurnal Ilmiah Pendidikan Dasar

Faradina, N. (2017). Pengaruh Program Gerakan Literasi Sekolah terhadap Minat Baca Siswa di SD Islam Terpadu Muhammadiyah An-Najah Jatinom Klaten. Jurnal Hanata Widya 6

Fasasi, R.A. (2017). Effects of Ethnoscience Instruction, School Location, and Parental Educational Status on Learners' Attitude Towards Science, International Journal of Science Education

Harsono, Y. M. (2007). Developing Learning Material for Specific Purpose. TEFLIN Journal

Huck, C.S., Hepler, S., \& Hickman, J. (1987). Children's Literature in The Elementary School. New York: Holt, Rinehart and Wiston.

Kemdikbud. (2017). Hasil Indonesian National Assesment Programme (INAP).

Kementrian Pendidikan dan Kebudayaan Republik Indonesia. (2016). Desain Induk Gerakan Literasi Sekolah. Jakarta: Depdikbud.

Klein, G. (2002).Reading into racism: bias in children's literature and learning materials. New York: Taylor \& Francis

Krisiandi. (15 Desember 2016).Daya Imajinasi Siswa Lemah. Harian Kompas

Marcus, L.S. (2013). Pop-Ups on Parade: Art, Novelty, and the Book Reimagined. New York: IPCNY

McLain,M., McLain,M., Tsai,J., Martin,M., Bell,D., \& Wooff, D. (2016). Traditional Tales and Imaginary Contexts in Primary Design and Technology: A case study. Design and Technology Education Journal

Mendikbud. (2019). Mengejar ke Barat, Utara, dan Timur. Retrieved from https://indonesia.go.id/kategori/indonesia-dalam-angka/1013/mengejarke-barat-utara-dan-timur

Nurgiyantoro, B. (2013). Sastra Anak. Yogyakarta: Gadjah Mada University Press

OECD. (2018). Indonesia-Country Note - Results from PISA 2015

Prastowo, A. (2014). Pengembangan Bahan Ajar Tematik:Tinjauan Teoritis dan Praktik. Jakarta: Kencana Prenada Media Group

Sarlatto, M. (2016). Paper Engineers and Mechanical Devices of Movable Books of The $19^{\text {th }}$ and $20^{\text {th }}$ Centuries

Schunk, D. (2012). Learning Theories An Educational Perspectives:Teori Pembelajaran Perspektif Pendidikan Edisi Keenam. Penerjemah: Eva Hamdiah \& Rahmat Fajar. Yogyakarta: Pustaka Pelajar

Syofyan, H., Zulela, \& Sumantri, M.S. (2019). Pengembangan Awal Bahan Ajar IPA Di Sekolah Dasar. JPD: Jurnal Pendidikan Dasar

Tianisa, W. T. (2017). Analisis Kebutuhan Buku Ajar Matematika Berbasis Model Pembelajaran Guided Discovery. The 5th Urecol Prosiding. Universitas Ahmad Dahlan 
26 | AR:-RIAYAH : Jurnal Pendidikan Dasar Vol. 5, No. 1, 2021

Triatma, I.N. (2016). Minat Baca pada Siswa Kelas VI Sekolah Dasar Negeri Delegan. E-Jurnal Prodi Teknologi Pendidikan

Vate-U-lan, P. (2011) Augmented Reality 3D Pop-up Children Book: Instructional Design for Hybrid Learning. Proceedings of IEEE International Conference, Melbourne

Wardani, P. T., Alwi, M., \& Hakim, A. R. (2020). Pengembangan Bahan Ajar Ipa Kelas $\mathrm{V}$ Sekolah Dasar Menggunakan Multimedia Interaktif Berbantuan Animasi. Prima Magistra: Jurnal Ilmiah Kependidikan 